\title{
The Usability Measurement of E-Faculty of Education UNESA Service Using USE Questionnaire
}

\author{
Mohammad Syahidul Haq; Wagino; Khofidotur Rofiah; Nur Aini Dwi Setyowati
}

\author{
Jurusan Manajemen Pendidikan, Fakultas Ilmu Pendidikan \\ Universitas Negeri Surabaya \\ Jl. Lidah Wetan No.1, Surabaya, Jawa Timur, Indonesia \\ E-mail:mohammadhaq@unesa.ac.id.
}

Article received: June 2021; revised: July 2021 ; accepted : August 2021

DOI : 10.17977/um025v5i32021p169

\begin{abstract}
In this 21st-century era, the development of a management information system is one of the efforts that can be made to improve the quality of public services, both in general and in certain sectors, for example, education, where because of the effect of industrial revolution 4.0 and society 5.0, these days the community often to use the assistance of technology for their social activities. One of many ways that can be used to measure the success rate of a system is using usability measurement. The usability level of an information system shows whether the system is accepted by the user or not. This study aims to measure the usability level of the educational service in the Faculty of Education, State University of Surabaya (UNESA), using the USE Questionnaire. The data from this research are processed using a descriptive statistics method and then analyzed both for each aspect and the correlation of all aspects. The results of this study included; (1) the usefulness aspect got an eligibility percentage of $83,6 \%$; (2) the ease of use aspect got an eligibility percentage of $81,7 \%$; (3) the satisfaction aspect got eligibility percentage of $79,8 \%$; (4) the result of calculation of all usability aspects are $81,9 \%$, meaning that the E-Service Faculty of Education, Unisa very useful and worthy to be used.
\end{abstract}

Keywords: Education; Management information system; Usability

the development of technology in the 21 st century is so fast. Currently, it is not only work-related to offices such as document creation and data storage that utilizes technological sophistication, but currently, social interaction in society has also used technological sophistication. The 21 st century requires society to change according to the times, coupled with the industrial revolution and the development of society in the 21 st century, all of which are carried out using technological sophistication. The development of the era in society also requires educational institutions to develop constantly.

Education as a forum for printing or producing human resources is required to produce a higher quality of generation so that a country can compete globally. The utilization of information and communication technology is carried out to improve the quality of human resources in an organization or institution (Amaliah, Soedjono, and Henderi, 2018:956). One of the efforts from the educational institutions to produce higher quality human resources is to provide the best service for using educational services, such as students, stakeholders, and the community because educational institutions are actually organizations in the service sector, so to satisfy service users, educational institutions are required to provide quality services.

The quality of service in an organization or institution that offers services is very important from the point of view of the customer (user). The customers will not only judge from the results of the service, but also from the process of delivering the service (Noer Cholidah, 2017: 81). Therefore, highquality services have an important role in shaping customer satisfaction (Kotler and Armstrong, 1996). Several research results show that service quality has an important role including, research conducted by (Liung and Syah, 2017), which showed the results that service quality affects Caiming Mandarin student loyalty. The next is research conducted by (Nurhadi and Azis, 2018), this research showed that service 
quality has a positive and significant effect on consumer confidence in PT. Pos Indonesia in Yogyakarta. In the modern era today, one thing that educational institutions can do to improve the quality of their services is to take advantage of the existence of a management information system. Research conducted by (Batari, Bima, and Rahman, 2018), also showed the results that service quality has an influence on Ford Car customer satisfaction at PT. Kumala Prima Motor Makassar.

Schronderberg (Fatta, 2007:3) explained simply that the system is a series of system components that are connected with several criteria. Management Information System (hereinafter referred to as SIM) is a management activity carried out by utilizing information systems in its application to an organization that is intended to provide the information needed by the organization. Gordon B. Davis, (1993) explained, MIS is a system consisting of humans or machines that provide information to support managerial activities and decision-making functions in an organization. In addition, Gordon B. Davis (Gordon B. Davis, 1993) also emphasized that MIS is always related to computer-based information processing. MIS is a system that performs the function of providing all the information that affects the operations of all organizations.

The development of management information systems also needs to be implemented in educational institutions because it is a part of improving service quality, educational institutions are required to provide accurate information quickly as a form of effort to face global competition, so that later they can become competitive advantages. The need for technology in an educational institution is also caused by the demands of increasingly high and complex needs so that a change occurs. The development of management information systems needs to be applied to educational institutions based on the principle of increasing efficiency and quality of public services. One of the objectives of implementing a management information system in educational institutions is to support management function activities, namely planning, organizing, staffing, coaching, evaluating, coordinating, and budgeting to support the realization of the aims and objectives of the operational functions of educational organizations.

To improve the quality of service, the Faculty of Education, State University of Surabaya developed an educational service by utilizing a management information system to facilitate students in accessing all needs regarding correspondence including resignation letters, lecture transfer letters, lecture leave letters, thesis forms, and invitations, research permit, observation permit, library cover letter, the lecture statement letter, lecture certificate, online-based article upload letter. This service is called the Academic Service Information System, Faculty of Education, UNESA.

The features that exist in the Academic Services of the Faculty of Education are as follows:

\begin{tabular}{|l|l|}
\hline e-Survey & $\begin{array}{l}\text { Survey activities conducted online on a matter to } \\
\text { collect data in improving the quality of services at the } \\
\text { Faculty of Education }\end{array}$ \\
\hline e-Lapor & $\begin{array}{l}\text { The service provides students to report an incident or } \\
\text { event that is not following applicable regulations or } \\
\text { student expectations through an electronic system }\end{array}$ \\
\hline
\end{tabular}




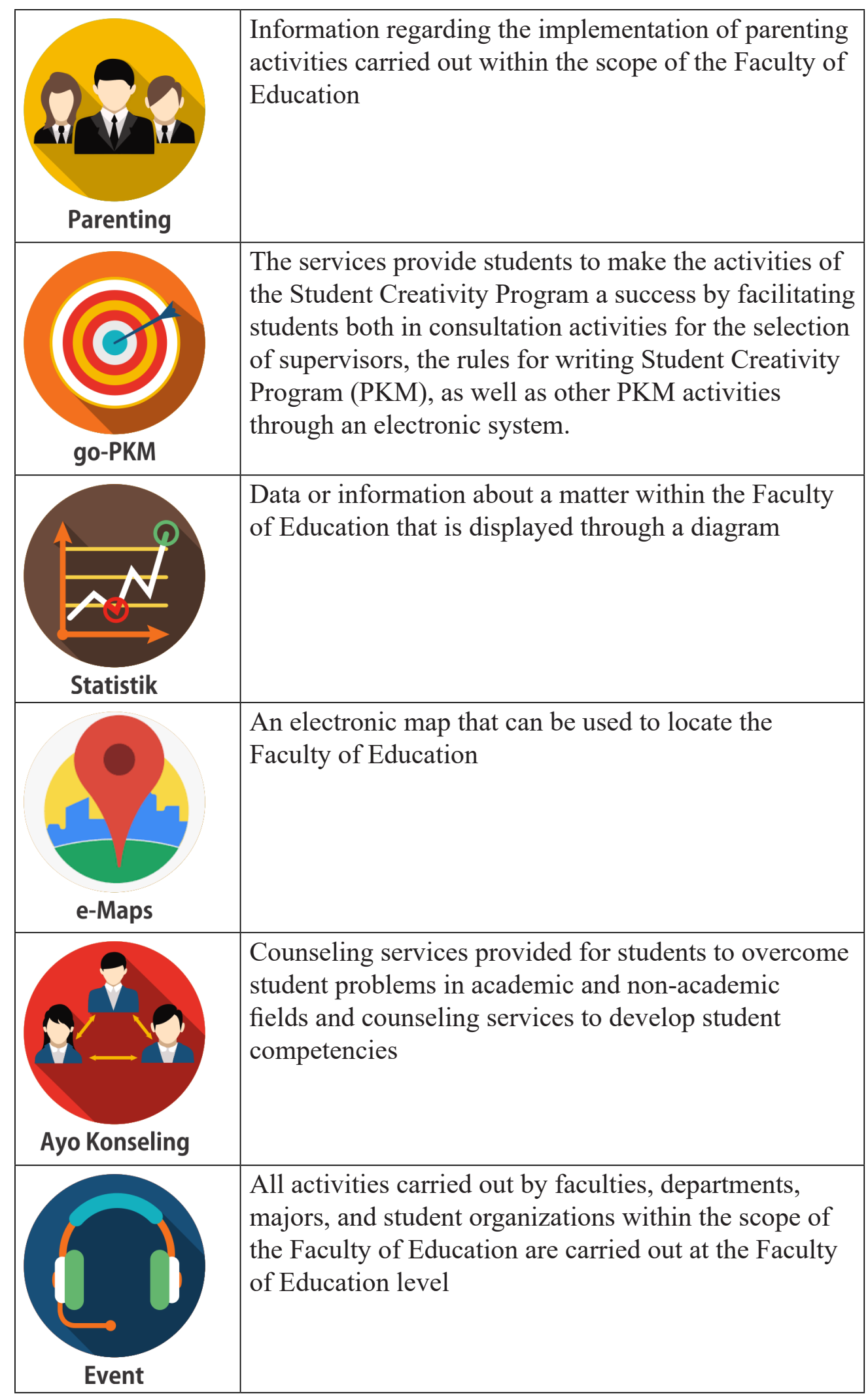




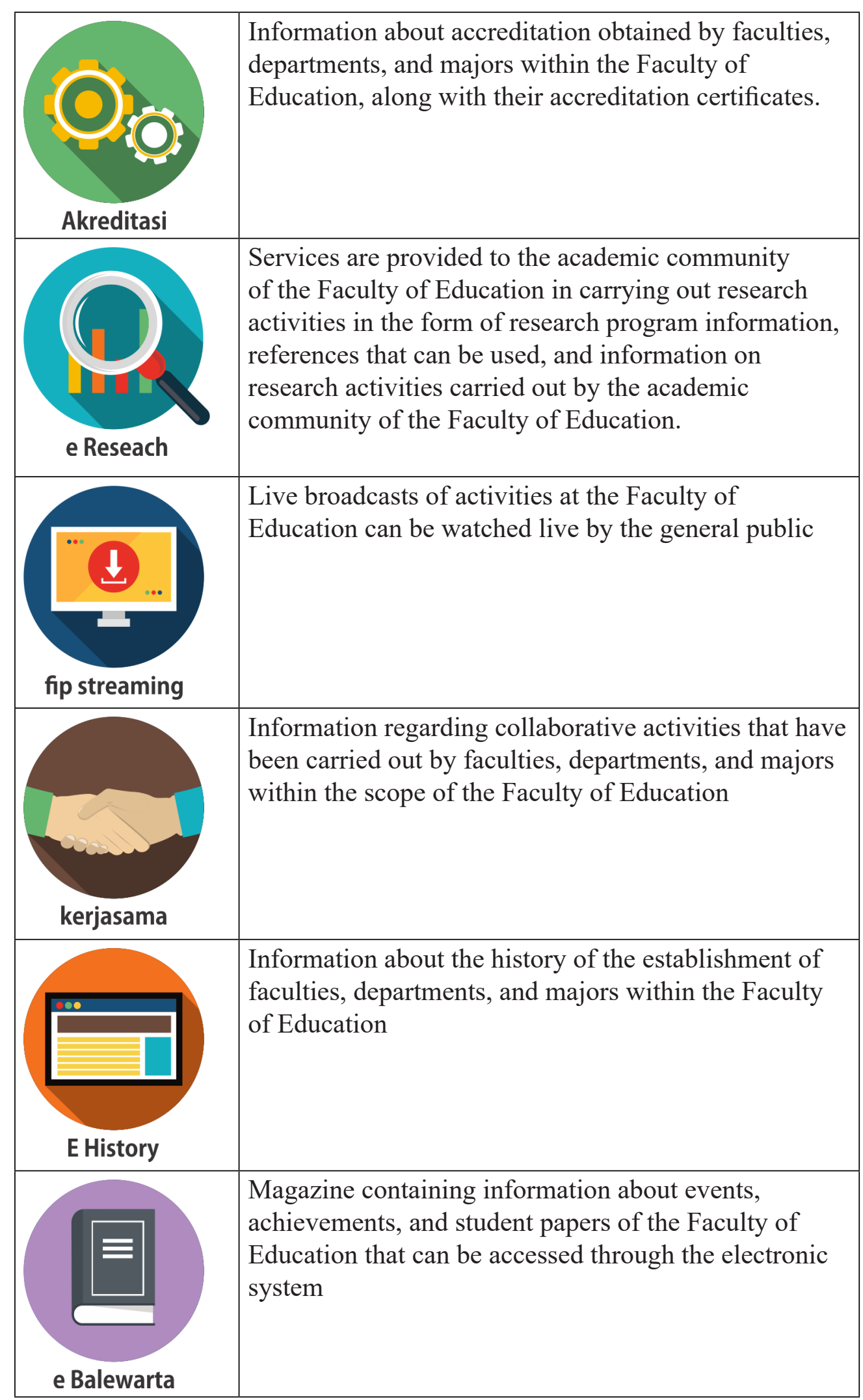




\begin{tabular}{|l|l|}
\hline & $\begin{array}{l}\text { Television containing information about activities or } \\
\text { activities carried out within the scope of the Faculty of } \\
\text { Education }\end{array}$ \\
\hline tv informasi & $\begin{array}{l}\text { Proceedings are published after national and } \\
\text { international seminars within the Faculty of Education } \\
\text { that can be accessed via an electronic system }\end{array}$ \\
\hline e Proceeding & $\begin{array}{l}\text { Information on environmental care activities or } \\
\text { programs carried out by faculties, departments, majors, } \\
\text { and student organizations }\end{array}$ \\
\hline e Form & $\begin{array}{l}\text { Forms that can be downloaded or filled out by students } \\
\text { to meet the needs of students in carrying out activities } \\
\text { within the scope of the Faculty of Education such as } \\
\text { research forms, graduation forms, and so on. }\end{array}$ \\
\hline \hline
\end{tabular}

\section{METHODS}

The purpose of a developed information system is to help humans work to run more effectively and efficiently. If the system can help humans to do their work more effectively, it means that the information system which has been developed is successful. One way that can be used to assess the level of success of an information system that has been developed is to use usability measurements. The usability level of an information system indicates whether the information system is accepted by the user or not. Information systems that have a high level of usability will make the information system much liked by users and can last a long time because it has a lot of regular users. And vice versa, if an information system has a low level of usability, even though it is developed according to the needs and uses a lot of resources, in the end, it will still be forgotten by the user. This study uses a usability measurement method by distributing questionnaires to several samples. The questionnaire used in this research is the USE Questionnaire.

Usability means the usability value of something, which comes from the same basic word, namely usable which means useful well. Something can be said to be useful if it can provide benefits and satisfaction to users and can minimize failures in its use (Rubin and Chisnell, 2008). Joseph Dumas and Janice Redish (1999) mentioned that usability focuses more on how users can achieve their goals by learning and using the product developed and how satisfied they are with its use. Meanwhile, the notion of usability according to ISO 9241:11 (1998) is the extent to which the product can be used to 
achieve the target set by a particular user, regarding aspects of effectiveness, efficiency, and satisfaction of certain users. User satisfaction is closely related to service quality (Dewi dan Sudiartha, 2018:4543).

Measuring usability means measuring effectiveness, efficiency, and user satisfaction. Usability measurement can be done through several stages, namely as follows:

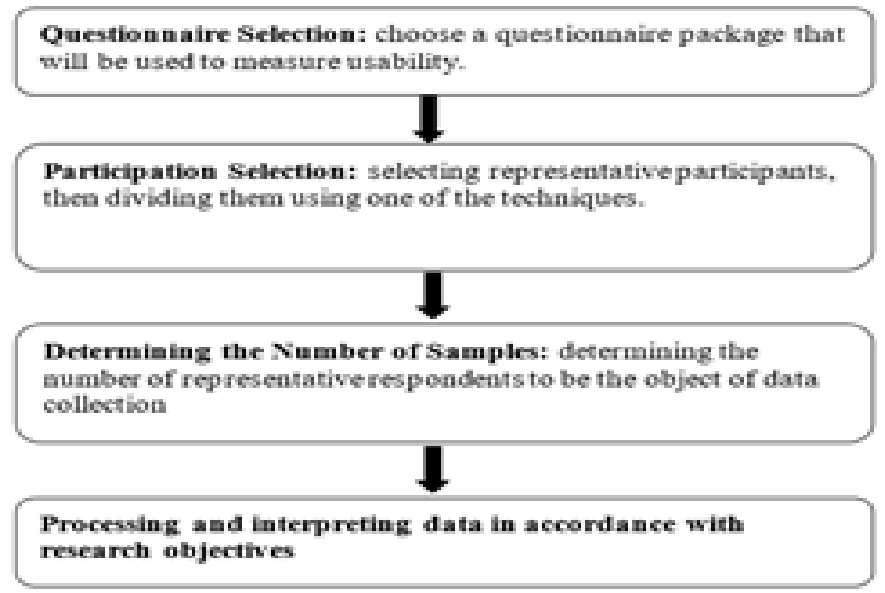

The data obtained from usability measurements are divided into four, namely nominal, ordinal, interval, and ratio. Each data type requires different data analysis techniques. Interval and ratio data can use descriptive statistics, namely t-test, ANOVA, and correlation calculations. While nominal and ordinal data types can use descriptive statistical data analysis techniques including, mean, median, mode, range, etc. In this study, the type of data used is ordinal (ranking), namely with assessment criteria 1 to 4 , which will be calculated using descriptive statistics.

One of the questionnaire packages that can be used to calculate usability is the USE Questionnaire. According to ISO, the USE Questionnaire includes 3 aspects of usability measurement, namely Usefulness (effectiveness), Ease of use (efficiency), and Satisfaction (satisfaction). Some studies mostly refer to these 3 aspects, although some of them also added other aspects, these 3 aspects are the easiest to observe and observe if you have to evaluate more than one product. The results of several studies also show a correlation and influence between Usefulness (effectiveness) and Ease of use (efficiency). If the aspect of Ease of use (efficiency) has increased, then the aspect of Usefulness (effectiveness) will also increase (Aelani, 2012).

The form of the USE Questionnaire package used in this research is as follows: Usefulness (effectiveness), E-Services help me be more productive, E-Services help me more effectively, E - Very useful service, E-Service helps me more easily to complete my work, The use of E-Service is very efficient, E-Service according to what I need, E-Service delivers everything according to my expectations.

Ease of use (efficiency): E-Service is easy to use, E-Service is very simple to use, User E - Very friendly service, E - The service has several steps I have to take to get what I want., E - Very flexible service, Using E-Service does not require much effort, I can use E-Service without written instructions, I did not find any inconsistencies during the use of E-Service, Infrequent users and regular users will both like E-Service, I can fix mistakes quickly and easily, I can use E-Service well all the time.

Satisfaction (Satisfaction): I am satisfied with the E-Service, I will recommend E-Service to my friends, E-Service is very pleasant to use, E-The service works the way I want it to, I feel I should use it (E-Service).

The questionnaire items were then made in the form of a four-point score using a Likert scale model, to measure the level of participants' agreement regarding the statements. The measurement results are then processed using descriptive statistics and analyzed both for each aspect, as well as the correlation between all aspects. 


\section{RESULTS AND DISCUSSION}

\section{Results of Analysis}

The development of information systems aims to facilitate activities carried out by humans, including in the field of education. Information systems are developed in the field of education in addition to facilitating activities in the field of education as well as to improve the quality of services provided by an educational institution, as well as those carried out by the Faculty of Education. The Faculty of Education, UNESA developed an information system that can be expected to improve the quality of academic services at the Faculty of Education, UNESA which was named E-UNESA Faculty of Education Services.

This study aims to measure the usability level of the E-Service Faculty of Education, UNESA using the USE Questionnaire. The USE Questionnaire is a questionnaire package that has three main aspects that must be investigated, namely usefulness, ease of use, and satisfaction. This questionnaire will later be given to 230 respondents randomly who are residents of the Faculty of Education, UNESA.

This research is later expected to provide information related to the level of eligibility with the E-Service Faculty of Education, UNESA, so that it can help institutions to improve existing deficiencies and continue to develop the information system.

\section{Results of Usability Measurement}

Usability measurement is done by calculating the percentage of answers from respondents using the formula proposed by Sugiyono, (2011), which is as follows:

\section{Number of observed scores Number of expected scores $\mathrm{X} 100$}

The calculated data will then be converted based on the eligibility category, as shown in Table 1.: Table 1: Table of Feasibility Category

\begin{tabular}{cc}
\hline Percentage (\%) & Classification \\
\hline$<21$ & Not feasible \\
$21-40$ & Less feasible \\
$40-60$ & Fairly feasible \\
$60-80$ & Feasible \\
$80-100$ & Very feasible \\
\hline
\end{tabular}

The usability calculation in this study was carried out by calculating the percentage of answers from all respondents according to three aspects of the USE Questionnaire, namely usefulness, ease of use, and satisfaction. The results of the usability calculation in this study are presented in Table 2.

Table 2: Table of Usability Calculation Results

\begin{tabular}{llccc}
\hline No & Usability aspects & Total Score of Respondents & Total Score & Number of feasibility (\%) \\
\hline 1. & Usefulness & 5.389 & 6.440 & 83,6 \\
2. & Ease of Use & 8.274 & 10.120 & 81,7 \\
3. & Satisfaction & 3.672 & 4.600 & 79,8 \\
& Total & 17.335 & 21.160 & 81,9 \\
\hline
\end{tabular}

The results of the calculation from the usefulness aspect get a total score of 5. 389 from the respondents. If the total score obtained from the respondent is divided by the total maximum score of the usefulness aspect, which is 6.440 , and multiplied by 100 like the formula above, it will get a feasibility percentage of $83,6 \% .83,6 \%$ in the table of eligibility categories included in the very feasible classification. Based on the results of the presentation, it can be concluded that the E-Service Faculty of Education UNESA is very useful for improving the quality of academic services of the Faculty of Education, UNESA. 
The results of the calculation of the second aspect, namely ease of use, get a total score of 8. 274 from respondents. If the total score obtained from the respondents is divided by the total maximum score of the ease of use aspect, which is 10.120 and then multiplied by 100 as in the formula above, it will get the percentage of eligibility of $81.7 \%$. The percentage (81.7\%), in the table of eligibility category, is included in the very feasible classification. Based on the results of the presentation, it can be concluded that the E-Service Faculty of Education, UNESA is very easy to use. This also means that users of E Faculty of Education Services do not find it difficult to use it.

The results of the calculation of the last aspect, namely satisfaction, get a total score of 3,672 from respondents. If the total score obtained from the respondents is divided by the total maximum score of the satisfaction aspect, which is 4,600 , and then multiplied by 100 as in the formula above, it will get the percentage of eligibility of $79.8 \%$. The percentage of eligibility $(79.8 \%)$ in the table of eligibility categories is included in the eligible classification. The results of research conducted by (Wati, Seta, and Isnainiyah, 2017), also showed that the satisfaction aspect has a significant effect on the usability of a product. Based on the results of the presentation, it can be concluded that the users of E-Service Faculty of Education UNESA are satisfied with the information system E-Service Faculty of Education, UNESA.

The results of the calculation of all aspects as a whole obtained a score from the respondents of 17. 335 , and the maximum total score of all aspects of 21. 160. If the total score of the respondents is divided by the total maximum score of all aspects of usability, then multiplied by 100 will get the percentage by $81.9 \%$. The percentage of eligibility in the table of eligibility categories is included in the very feasible classification. Based on the results of these calculations, it can be concluded that the E-Service Faculty of Education, UNESA is very feasible to use.

\section{CONCLUSION}

Based on the calculation results of the three usability aspects, it can be concluded; (1) the usefulness aspect has a feasibility percentage of $83.6 \%$; (2) the ease of use aspect gets a feasibility percentage of $81,7 \%$; (3) the aspect of satisfaction gets a percentage of the feasibility of $79.8 \%$; and (4) the results of the calculation of the overall usability aspect show the percentage value of the feasibility of $81,9 \%$. This proves that the E-Service Faculty of Education, UNESA obtains a very feasible percentage of feasibility, both based on each usability aspect, namely usefulness, ease of use, and satisfaction, also based on the results of calculations from all aspects. Therefore, it can be concluded that the E-Service Faculty of Education UNESA is very useful, easy to use or operate, and the users are satisfied with the E-Service Faculty of Education, UNESA.

Every implementation of a product should have advantages and disadvantages. Likewise in the development of educational services based on this website, based on the calculation results, the satisfaction aspect is the only aspect that has not to achieve a very feasible classification. Therefore, for the authorities to develop the E-Services Information system of the Faculty of Education, UNESA, maybe in the future they can improve this information system even more so that later the satisfaction aspect can also achieve a very feasible classification, and the users will also feel more satisfied.

\section{REFERENCES}

Aelani, Khoirida \& Falahah. 2012. "Pengukuran Usability Sistem Menggunakan USE Questionnaire (Studi Kasus Aplikasi Perwalian Online STMIK “AMIK BANDUNG”. Seminar nasional aplikasi teknologi informasi 2012 (SNATI 2012). Retrieved from journal.uii.ac.id database.

Amaliah, Khusnatul., Soedjono, Bambang., Henderi. 2018. "Evaluasi Usability Sistem Informasi Hasil Belajar (SISKO) Pada SMAN I Mlati Sleman”. Konferensi Nasional Sistem Informasi

Batari, Andi., Bima, Muh. Jabar \& Rahman, Zainuddin. 2018. "Pengaruh Kualitas Pelayanan dan Citra Merek Terhadap Kepuasan Konsumen Mobil Ford”. SEIKO, Journal of Management and Business, Vol. 2, No. 1, Hlm. 1-10 
Davis, G. B. 1993. Kerangka Dasar Sistem Informasi Manajemen. (Terjemahan Andreas S. Adiwardana). Jakarta: PT. Pustaka Binaman Pressindo.

Dumas, Joseph S. dan Janice C. Redish. 1999. A Practical Guide to Usability Testing.Revised Edition. Bethesda, USA : Redish \& Associates, Inc.

Dewi, Cokorda Istri Agung Krisna \& Sudiartha, I Gede Merta. 2018. "Pengaruh Kualitas Layanan dan Kualitas Produk Terhadap Kepuasan Nasabah Bank Pembangunan Daerah Bali”. E-Jurnal Manajemen Unud, Vol. 7, No. 8, Hlm. 4539- 4569

Fatta, Al Hanif. 2007. Analisis dan Perancangan Sistem Informasi. Yogyakarta: Andi

ISO 9241-11. 1998. Ergonomic requirements for office work with visual display terminals (VDTS) - Part 11: Guidance on usability

Kotler, P \& Armstrong, G. 1996. Dasar - Dasar Pemasaran, Edisi V, Jilid 2. Jakarta: Intermedia

Liung, Hon \& Syah, Tantri Yanuar Rahmad. 2017. "Pengaruh Kualitas Layanan Terhadap Kepuasan dalam Meningkatkan Loyalitas di Moderasi Harga”. Jurnal Ekonomi, Vol. 8, No. 2, Hlm. 32-44

Noer Cholifah. 2018. "Pengaruh Kualitas Pelayanan Terhadap Kepuasan Pelanggan (Studi Orenz Taxi) di Surabaya". BISMA - Bisnis dan Manajemen, Vol. 9, No. 2, Hlm. 80-90

Nurhadi dan Azis, Asriel. 2018. "Pengaruh Kualitas Pelayanan Terhadap Kepercayaan dan Kesetiaan Konsumen". Jurnal Economia, Vol.14, No. 1, Hlm. 89-98

Rubin, Jeffrey dan Dana Chisnell. 2008. Handbook of Usability Testing: How to Plan, Design, and Conduct Effective Tests (2nd edition). IN: Wiley Publishing, Inc.

Sugiyono. 2011. Metode Penelitian Kuantitatif, Kualitatif dan R\&D. Bandung: Alfabeta

Wati, Theresia., Seta, Henki Bayu dan Isnainiyah, Ika Nurlaili. 2017. "Pengukuran Usability dan Evaluasi E-Learning untuk Program Pelatihan bagi Tenaga Kependidikan”. Jurnal Pekommas, Vol. 2, No. 2, Hlm. 177-184 